\title{
Growth in WEIRD Helsinki: Countering Dominant Urban Politics and its "Green" Pretentions
}

\author{
Eeva Berglund, Guy Julier
}

\begin{abstract}
Despite persistent concerns over sustainability, cities continue to be developed that serve capital more than citizens. Where urban politics prioritizes growth, "green" credentials easily turn out to be illusory. Helsinki, with its pro-environmental administration, is an example of combining "green" agendas with a culture of growth and depoliticizing debate. This essay presents two cases of this broadly ecomodernist approach. In one case this approach led to proposing the destruction of irreplaceable green space and in the other, to drawing residents into international circuits of finance and data. This problem does not just emerge from corporations and elites, however. Drawing on Harvey Molotch's idea of "the city as growth machine", we suggest that growth ideology reflects a culture that, following psychologists, we might call WEIRD: Western, Educated, Industrial, Rich and Democratic. Its claims are founded on a historically particular but widespread conception of global progress that is increasingly questioned.
\end{abstract}

KEYWORDS the neoliberal city, urban growth, "green" growth, planning for sustainability, degrowth, Helsinki

\section{Introduction}

As one of many protest actions, in 2015 activists lay down on the stone floor of Helsinki's railway station and put paper crosses on their chests to "save" Vartiosaari (Oinonen 2015), a lush island 10km east of the city centre, from being developed into suburbia. Meanwhile, students of sustainable planning and design find in Vartiosaari the perfect site for exploring the possibilities of making urban development less destructive. While the regional planning authority promotes "the sustainable steering of growth" ("kasvun kestävä ohjaaminen”, Uudenmaan Maakuntahallitus 2019), some design students are less convinced, one noting that, "In the end I feel like no matter how well I design the given area it can never compete with the beauty and quality the island has in its present state" (Arjanko 2015: 8).

Further west, controversial high towers and a shopping mall in the Kalasatama "smart" development remind Helsinkians of the rapidity of contemporary construction. Part of a grand overhaul of Helsinki's post-industrial waterfront (Ameel 2016), it doesn't just alter the landscape, it generates a steady stream of advertising that exploits a range of narratives and their counter-currents. The idea that Kalasatama is taking Helsinki

Sociální studia / Social Studies 1/2020. S. 13-31. ISSN 1214-813X. 
"closer to the world's leading metropolitan centres" is supported by promises of easy city living where "everything works, everything is close by and everywhere is easy to get to", as in an advertisement by SRV on the cover of Helsingin Sanomat newspaper (2019). Kalasatama features a range of pilot projects with green aims, such as electric car-sharing systems, smart waste disposal systems, local solar power production and bespoke digital applications designed to reduce consumers' carbon footprints (Smart Kalasatama n.d.). Their actual impacts on local or global environmental quality are unlikely ever to be established. Meanwhile, its residents are inextricably linked to international circuits of data and finance. Everyday life here is being hardwired into a growth agenda.

In this essay, we take up the perspective of the critics and draw inspiration from the many different emergent projects exploring alternatives that we have studied. Aligning with them, we approach Helsinki's noticeably accelerated growth imperative, like urban growth ideology generally, as something that needs explaining. We deem it insufficient to blame, as local discourse tends to do, either globalization or (greedy) decision makers for today's unhappy and intellectually muddled urban politics. In this we are inspired by Hyötyläinen and Haila (2018: 143), whose work on Helsinki identified how "entrepreneurial real estate policy practised both by the state and cities had harmful consequences and created conflicts in Finland". Our aim is to develop this further, to identify the associated material and ideological processes at stake in Helsinki and connect these to wider global and institutional structures of neoliberal financialization and urban growth.

We therefore consider the current iteration of planning in Helsinki as a kind of ecomodernism. ${ }^{1}$ Set within a legacy of the growth syndrome, such urban development takes notions of "green" or "sustainable" to set the management and shaping of "nature" and "technology" in the city side-by-side. We argue that this clouds and depoliticizes the destructive agency of much economic growth, whether felt locally or elsewhere. Specifically, we argue that both the proposed "close-to-nature" Vartiosaari development and the Kalasatama "smart city" concept serve to greenwash the urban growth agenda.

Both the Vartiosaari and Kalasatama projects illustrate how "green" agendas have been folded into such urban politics. For instance, Finland has the declared aim of being carbon neutral by 2035; in Kalasatama the aim is to achieve this by 2023. Developing Vartiosaari was conceived as modern living close to nature, part of a wider programme for sustainable transport. However, in the ins and outs of how such things are assessed, crucial questions have been left aside about how these green aims are to be achieved, within what ideological and techno-political frameworks, and how they are conceived in terms of political economy. These questions are relevant anywhere that politics and decision-making are both pro-growth and pro-environment: our perspective on Helsinki attends to local specificities without ignoring wider geographies. The capital of a wealthy and stable nation-state, Helsinki likes to emphasize its "green" credentials, from forested landscapes to resource efficient everyday life, and it boasts substantial urban green space despite recent densification (Hannikainen

We see "ecomodernism" as an ideology that embraces technological development and economic growth as the leading way of addressing the world's economic, social and environmental challenges (Asafu-Adjaye et al. 2015). 
2019). As we will show, its development vindicates the argument that normative but semantically loose language compromises urban planning (Davidson 2010; Granqvist et al. 2019). As elsewhere, fuzzy notions of "green" and "sustainable" narrow down political space (see e.g. Swyngedouw 2013; Kaika 2017) and obscure persistent and possibly worsening unsustainability (e.g. Lawrence 2017; Blühdorn and Deflorian 2019).

\section{Activist Research and Neoliberalism in Helsinki}

We are activist-researchers based in Helsinki. Berglund is an anthropologist who has, over the past decade, been engaged in organizing and participating in various environmental actions and interventions within the city, including in Vartiosaari. Since the mid-1990s, she has researched forest politics and their relationship to environmentalism in Finland. Within Helsinki, she co-edited a book on urban development and architecture, which deepened her engagement with key actors and debates within its urban activist milieu (Berglund and Kohtala 2015). By bringing activists and researchers together, the project became a recursive device, opening onto and surfacing the interconnected patterns of urban development and activism. Julier is a specialist in economies and cultures of design in the context of urban transformation, promotion and policy (e.g. Julier 2005) while also engaging practically and conceptually in urban design activism (e.g. Unsworth et al. 2011; Julier 2011). Since moving to Finland in 2018, he has been researching the development of Kalasatama as a rationalized landscape.

This paper draws together theoretical overviews of processes of neoliberalization and urbanization with close readings of a range of relevant primary sources in Helsinki. The latter includes grey literature documents produced by key actors in the development of the city (e.g. City of Helsinki, Helsinki-Uusimaa Regional Council, major property developers, professional literature aimed at planners), as well as media commentary and activist debates (e.g. as followed in the Helsingin Sanomat newspaper, the national broadcaster YLE and on social media).

Our position with regard to the wider questions of social practices and neoliberal political economies in contexts such as Finland is one that combines critical perspectives on governmentality (even environmentality, Luke 1995) with Marxist post-structural positions (e.g. Springer 2012). We don't see these as mutually exclusive. Rather, we take neoliberal practices of flexible accumulation and inter-urban competition as being multisited, from the larger structures of national and metropolitan economic policies and priorities to everyday, bodily dispositions. We understand that one can't exist without the other. Between these, we also pay attention to mediating systems - such as design, marketing and advertising - that enculture and naturalize human agency, making "reasonable" the processes of change that are embedded into the multifarious and often self-contradictory machinations of neoliberalization (Julier 2017). To query this "reasonableness", we employ the concept of WEIRD (Western - Educated - Industrial - Rich - Democracies) from social psychology (Nielson et al. 2017), which we explain later in this paper.

In this wider context of neoliberalization, Helsinki's urban debate appears both deflated and angrier at the same time. But it is also the case that the intensified large-scale urban 
construction that provokes debate there is part of global processes that bring destruction to landscapes while triggering rural depopulation at the same time (Fredriksson and Normo 2019). These urban processes are "common-sense" aspects of modernity, their continued and global spread considered both inevitable and desirable. With this grand historical trajectory associated with the industrial city, a tenacious fantasy has also emerged in which personal aspirations and successes are achieved in big, dynamic, growing cities. The institutional effect of this has been to entrench a rhetoric of competitiveness at regional and city levels. As Harvey Molotch famously put it in 1976 in the American Journal of Sociology, "The city is, for those who count, a growth machine" (p. 310).

The growth syndrome, as Molotch called it, has Helsinki, like many other cities, well in its grip. Repeating numbers, for instance, that serious and, no doubt, influential estimates expect the city's population to grow from its current 650,000 to 822,000 by 2050 , is one illustration and enactment of this. What interests us here is that the conditions of community life, as Molotch wrote, "are largely a consequence of the social, economic, and political forces embodied in this growth machine" (1976: abstract). While perhaps sympathizing with the critics, including local residents, Finnish planning and construction professionals take as given that "there is no alternative" to urban growth (e.g. Schulman and Mäenpää 2011; Wallin 2018).

If this pits environmental values against economic ones, realpolitik often leads to claims that it is too expensive to be green and so follows the neoliberal tenet that economic value is an index of the right thing to do (Mirowski 2013). This is despite, at least in Finland, opinion surveys suggesting popular support for putting nature before profit (e.g. YLE 2019). To be sure, economic growth and the urban growth that is presumed to underpin it remain very vague notions. However, decades and longer of critique have barely - up to now - dislodged or replaced the growth imperative. If the social consequences of growth ceasing are hugely problematic - portending social unrest even - this does not change the intellectual poverty that the growth syndrome has sustained, colonizing as it has "our minds, our political system and the world economy. The concept of growth is not just depoliticised, it's also naturalised, in a way that it's considered like something human civilizations have always aimed for" (Stefania Barca in Chertovskaya et al. 2017: 193).

Numerous scholars have looked to the cultural and material histories of modern industrial cities in order to articulate compelling arguments linking desires for endless economic growth to metropolitan enthusiasms (e.g. Berman 1982; Harvey 1989). These support elite identities of one sort or another while treating the city as an artefact that is a disembedded and detached spectacle, divorced from its ecological and extractivist dependencies. The subject of this history has been the consumerist and aspirational homo oeconomicus. We see the continuation of this in the boosterish image-mongering that still accompanies the promotional cultures of the entrepreneurial city (Hall and Hubbard 1996; Quilly 2000; While 2004).

What Molotch called the "general irrationality of the present urban system" (1976: 329) of the 1970s USA, remains an aspiration for European cities today. It has meant subordinating local politics to a competition between places where, by definition, some become losers. Gradually, critical debate does appear to be gaining momentum (Demaria et 
al. 2019), but critique of the growth syndrome is voiced more easily than committed to print (for exceptions, see Lehtinen 2018) and it would be very premature to say that it is losing its hegemonic grip. Something so vague and at the same time deeply embedded in infrastructures and subjective experiences will not be easily dislodged (Springer 2012).

It is well to remember here that neoliberalism "necessarily operates amongst its others" in its parasitic qualities (Peck et al. 2009: 104) and is therefore able to draw in and instrumentalize a panoply of different aims, motivations and subject positions. Thus, we do not find it inconsistent in itself, let alone unusual, that a city would espouse ambitions of carbon-neutrality and other efforts to be sustainable while being deeply committed to its own growth in all kinds of ways. Neoliberalism, like Helsinki, indeed, is weird and it requires weirdness to continually function and unfold in the ways that it does.

\section{De-politicization and Co-optation}

The growth syndrome appears to compel well-educated and politically committed people to support it even where they fear that this will close off the kind of radical sustainability that long-term human wellbeing demands (Demaria et al. 2019). Attitude surveys, for instance, show that people do often put environment before wealth, in Finland (YLE 2019) as elsewhere (Kysela 2015). In practice, though, as these surveys also note, actions speak louder than words, so that in reality people and institutions choose economic benefit over environmental good. Combining sustainability with economic growth or "development", as in green growth or ecomodernism, reduces the cognitive dissonance. This is evident, for instance, in policy documents that employ the language of sustainable growth. Arguments for it are enhanced by targets of carbon neutrality by 2035 and promises of further cost-efficient management of the urban environment (Helsinki City Strategy 2018). Presenting Helsinki's growth as green was crucial to the city's efforts to develop the island of Vartiosaari. Yet developing it would mean consuming land for urban infrastructure and compromising lively ecologies. Equally, green values have also been used to promote the construction of commercially financed and efficiency-driven hubs like Kalasatama.

It is important not just to consider the unsustainability of these places in themselves, but, crucially, the externalities that they provoke. Urbanization has its others, not least in shrinkage of and drainage from its hinterlands (Haughton et al. 2014). Thus, for example, the growth of Helsinki involves contraction or stasis elsewhere in the country, for example, towns like Lahti, Hamina and Salo, not to mention small villages. The loss of infrastructures of support (transport, access to welfare services, jobs) produces depopulation and vice-versa. And while Finnish government policies have historically tried to support regional economies, these attempts appear not to have worked or have been abandoned altogether (Kotilainen et al. 2016). The development of one place does provoke decline elsewhere. At the same time, urban concentration produces more unsustainable practices - international travel, industrialized food systems, reliance on carbon-producing digital systems and so on (Heynen et al. 2006; James 2014).

Projects that "densify" existing concentrations of people now appear as the only way for local politicians to secure the welfare of citizens, even though they fall far short 
of the fine-grained socio-ecological sustainability that the city claims to foster. It is in these moments of realpolitik that even environmentalists have been compelled, as Giorgos Kallis has noted, to stop saying "no" (Chertovskaya et al. 2017: 192). Saying "yes" to false consensus under the pressure of "urgency" has made environmental politics progressively more technocratic and managerialist at a global scale. Meanwhile, participatory governance and its often middle-class biases at the local level operate as a kind of "opium for the masses" (Alain Badiou in Swyngedouw 2013). Unable to overturn the growth story, many environmentalists have joined business and government in promoting implausible win-win solutions as part of the oxymoronic project of sustainable development (Chertovskaya et al. 2017: 192).

If green agendas are open to co-optation (Swyngedouw 2013; Kaika 2017) and greenwashing is a common gambit in place-competition, Finland's low population density and the small size of even its biggest cities $^{2}$ have fostered a dominant view that environmental problems are relatively minor, and in any case, they are something for rural areas to deal with. This narrative is the background against which Helsinki's urban policy and aspirations now develop. The idea that today's unprecedented sustainability challenges will be solved in urban areas (e.g. Vapaavuori 2018) supports this view, but it also fuels the impression that it is natural as well as desirable, from an ecological perspective, that Finland's largest cities should continue to grow.

This is one route for combining concern for nature with growth projects (Kaika 2017; Blühdorn and Deflorian 2019), and even for translating environmental quality into quantitative questions suited to neoliberal epistemology (Mirowski 2013). In Finland, this translatability partly stems from a history of expert regimes working to support the forestry sector. For decades this has meant that campaigning and policy making have tended to unfold in quantifiable language with scientific argumentation prominent (Berglund 2001). As an element of Finland's consensual policy style where industry and environmental organizations negotiate, effort has even gone into "normalising the population, as well as companies and public organisations, into disciplined environmental subjects", to quote policy researcher Rauno Sairinen (2003: 13). The legacy of forest-dependency produced an influential narrative according to which the country always has and always will manage this renewable resource in the wisest way possible, not for romantic environmentalist reasons, but for sound and universally agreed upon economic reasons. In sum, both urban and rural lives have long been shaped by projects of rationalizing landscapes. It has become common sense that nature must be managed, just as it is pressed upon the public that the city must be green - in all senses.

When David Harvey argued that "there is nothing unnatural about New York City" (1996: 186; italics in original), he might have been taken to be making a similar point, but he also went on to look at the power-relations that shaped its history. Similarly, we want to avoid fudging the issues brought up in acknowledging the hybridity - the artificiality as well as the

Only nine towns have a population over 100,000. Three of them, Helsinki, Espoo and Vantaa, together with Kauniainen, make up the capital city region, with a combined population of a little over one million. 
naturalness - of the environments that people (and others) must live in. It is an historical fact that human, specifically modern, artefacts are now continuous with the biotic systems that support life. Any discussion of sustainability must attend to the "tight couplings between natural, technical, political-economic, social, and discursive systems, all of which are aging, often overwrought, ossified and politicized" as Kim Fortun (2014: 310) has noted. Fortun, like Harvey, seeks to make visible the politics here.

It is worth noting that as a shorthand for the impact of human activity on the Earth, the Anthropocene concept might have a similar depoliticizing effect, being easy to present as an unrivalled opportunity to innovate in the way we know how - that is, technologically (Lawrence 2017; Hamilton 2015). It does not follow, however, as growthfriendly ecomodernism would have it, that being technologically sophisticated, we humans of the Anthropocene can transcend the problems currently causing so much trouble. Rather, the technological optimism long associated with the politics of sustainability appears increasingly as a sleight of hand, a way of trying to make what is very probably unsustainable simply appear sustainable, or to turn environmental policy making into a theatre for securing public acceptance of policies that support the established order (Blühdorn and Deflorian 2019). As if that were not bad enough, post-political environmental consensus leads to a politics that is reactionary and elitist (Swyngedouw 2013).

The depoliticizing thrust of a profit-friendly sustainability consensus is only partial, though. For those who look for it, there is genuine and not just semantic disagreement about what green agendas are and how they should be progressed. For instance, Maria Kaika (2017) argues that decision-making rooted in United Nations-level agreements, notably the New Urban Agenda and what she calls "greening by numbers", may be loved by media and policymakers, but close examination shows populations around the world have been rejecting the depoliticizing rhetoric of "inclusion" and "participation". That is, people are refusing to reduce urban politics to the production of "safe, resilient, sustainable and inclusive" spaces and to the "systematic monitoring and reporting" of all this activity (Kaika 2017: 92). People are aware that digital technologies designed to promote a universal conception of what is sustainable and what might be a quantifiable indicator of it, ignore significant differences among residents in terms of safety, inclusiveness or cultural values.

In Helsinki too, sustainability projects married to the growth imperative are locking people into financialization, monetization, ubiquitous surveillance and the censoring effects of the digitalized economy, while almost all main political parties in Helsinki, Greens included, prioritize planning for growth, making it not just a growth machine but a "green" one. Yet alternative imaginaries and organized forms of resistance do exist. From these perspectives, it starts to look as if it might actually be the growth syndrome itself that is peculiar, both in the sense of being the outcome of contingent histories and in the actual sense of being odd or weird.

\section{The Rational Landscapes of the "Green City"}

Residents of Helsinki have become used to promotional material featuring future cityscapes, as well as hyperbolic headlines such as this, from Ilta Sanomat [IS] on 3.6.2017, "IS-Report: 
Finland's cities will be revolutionized - Will Helsinki get the Manhattan of the Nordics?" The news item went on: "Skyscrapers, art districts, pedestrian city... Finland will be more urban than ever, when the demands of population growth and internationalization are responded to with solutions never seen here before" (Figure 1).

Figure 1: Promotional materials and news coverage about Helsinki's future

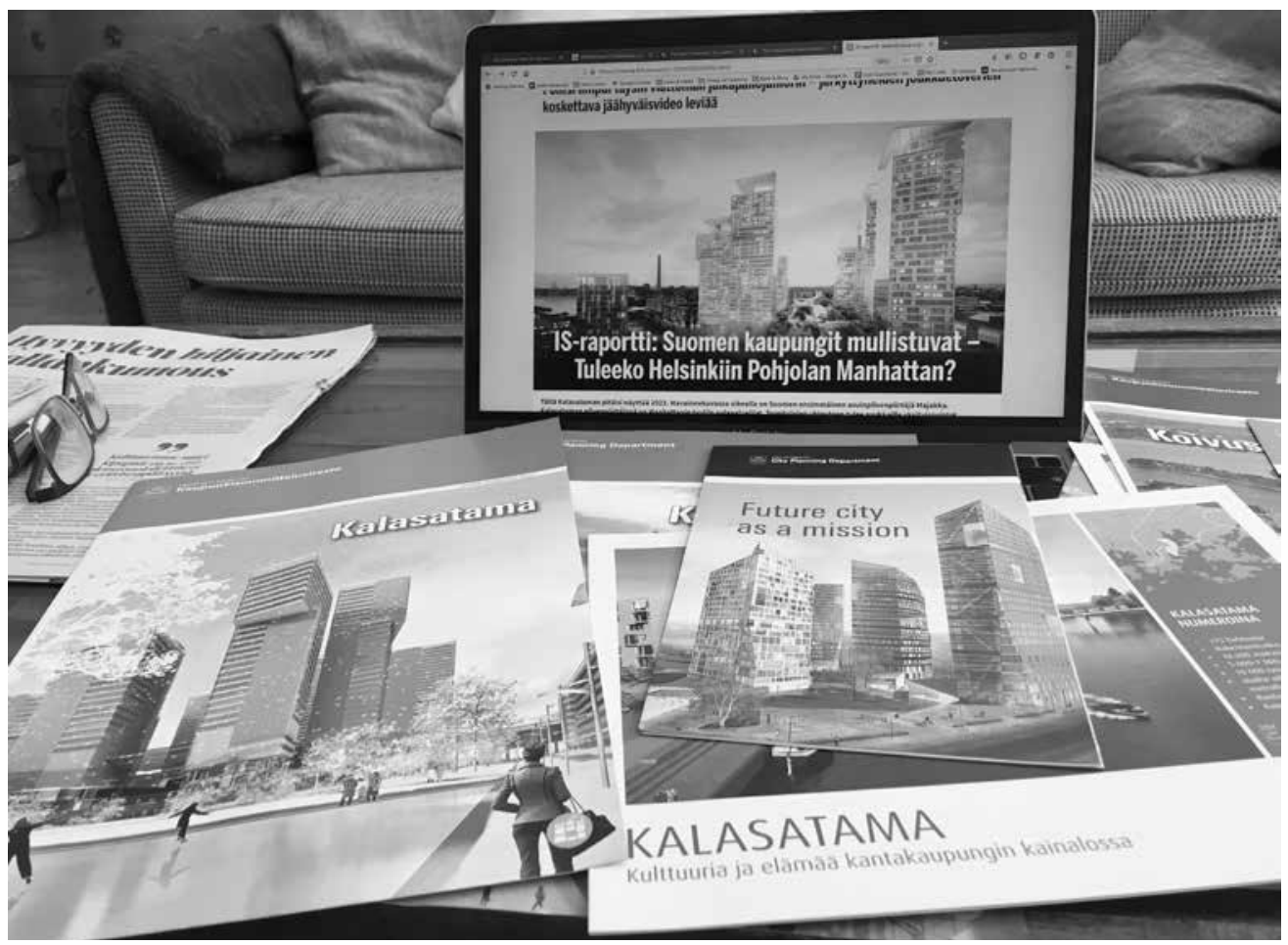

Source: Guy Julier

Since 2010, Helsinki has experienced a construction boom. The city council has built a marketing campaign around urban development and sustainability while pushing several landscape-altering schemes into the pipeline or into construction. The official discourse is not quite as breathless as the rhetoric of an afternoon paper, but even in 2008, that is, before the construction boom started, the city's own communications emphasized the need to keep Helsinki on a path to growth (e.g. Uutta Helsinkiä, n.d.). As specific schemes draw public attention, developers and the city claim that change is not just good but inevitable. Population growth and economic growth are both written into the political aims of the city. So is "functionality", today combined with a stock list from the business media's arsenal of property slogans: Helsinki is living, original, agile, and of course, responsible and sustainable. The actors involved in city construction seek to make Helsinki attractive to investors 
and high-end consumers as well as ordinary citizens who are considered necessary, as "good tax payers", to effective municipal housekeeping. ${ }^{3}$

However, on the ground, construction is an inconvenience or worse. It also threatens qualities of place that Helsinkians and tourists alike profess to value, like the largely natural waterfront and the city's low-rise skyline (Vanolo 2008). Tensions have revolved particularly around the new development plan, the City Plan ${ }^{4}$ of 2016 (Ameel 2016; Granqvist et al. 2019); but lively debate is, of course, neither new nor problematic as such. What has changed is how the municipality relates to the growth syndrome. Its actions are arguably exacerbating growth's negative effects rather than, as in the past, mitigating them (Hyötyläinen and Haila 2018), while the now routine appeal to all things sustainable complicates critique.

In planning to attract higher income residents, Helsinki's trajectory is typical of wealthy cities in Western democracies, with visible transformations in its central waterfront locations. Many were vacated in 2008 when a new container port was opened in the eastern suburbs, "unlocking" commercially attractive land in the centre for new development. The sites are large and so offer planners and developers enviable opportunities to design future neighbourhoods almost on a blank slate. The changes, in addition to pressure to build high, have already impacted on the city's silhouette and attracted not always kind commentary from former fans. Local as well as overseas commentators have noted that Helsinki is no longer the easy-tonavigate, compact, architecturally and culturally interesting city it was (Bennie 2015; Glancey 2015) even if it does still enjoy relatively low levels of the kinds of urban problems experienced in larger conurbations. Characterizing it as "privileged" in terms of its urban problems (Vanolo 2008: 233) seems justified. And as noted, greenspace - forests, parks and other - still abounds despite pressures on it (Hannikainen 2019). In sum, Helsinki's culture and even its technology continue to display typically Nordic social and ecological virtues.

Even the drive towards urban compactness is seen as an environmentally motivated corrective to decades of inefficient land use, with infill and densification robustly promoted through arguments that Helsinki is a laggard in sustainable planning. An interesting case has been the Facebook-mediated network YIMBY-Helsinki (Lisää Kaupunkia Helsinkiin -facebook group). The influence of this "Yes-In-My-Back-Yard" (hence YIMBY-Helsinki) enthusiasm for compactness on how the 2016 City Plan was drawn up has been much debated in social media as well as among researchers. ${ }^{5}$ Marketing-rhetoric aside, Helsinki really has become a denser, higher and more urban, and also more cosmopolitan place than it was only ten or twenty years ago (see, for example, City of Helsinki 2013).

Success from the point of view of the growth machine can amount to losses for existing residents, however. In Vartiosaari, for instance, plans for growth threatened to destroy green space and so shut down processes that tend towards sustaining natural metabolisms.

3 Helsinki's situation-specific governance challenges, including differential pressures on construction land, are highlighted in much academic and professional debate, but while this is certainly an important factor in shaping Helsinki's political and spatial imaginaries, it is not our point. For that debate, see e.g. Granqvist et al. (2019).

$4 \quad$ Also referred to as a master plan.

5 Mostly in Finnish. See e.g. Kaupunkiaktivismi website. 
Kalasatama, our other case, is not greenfield but brownfield development, promoted through the green values of smart sustainability. It appears as an inevitable victory of unassailable economic forces: greenwashed or genuinely interesting for its technological innovations, depending on your viewpoint.

Figure 2: Vartiosaari, summer 2015

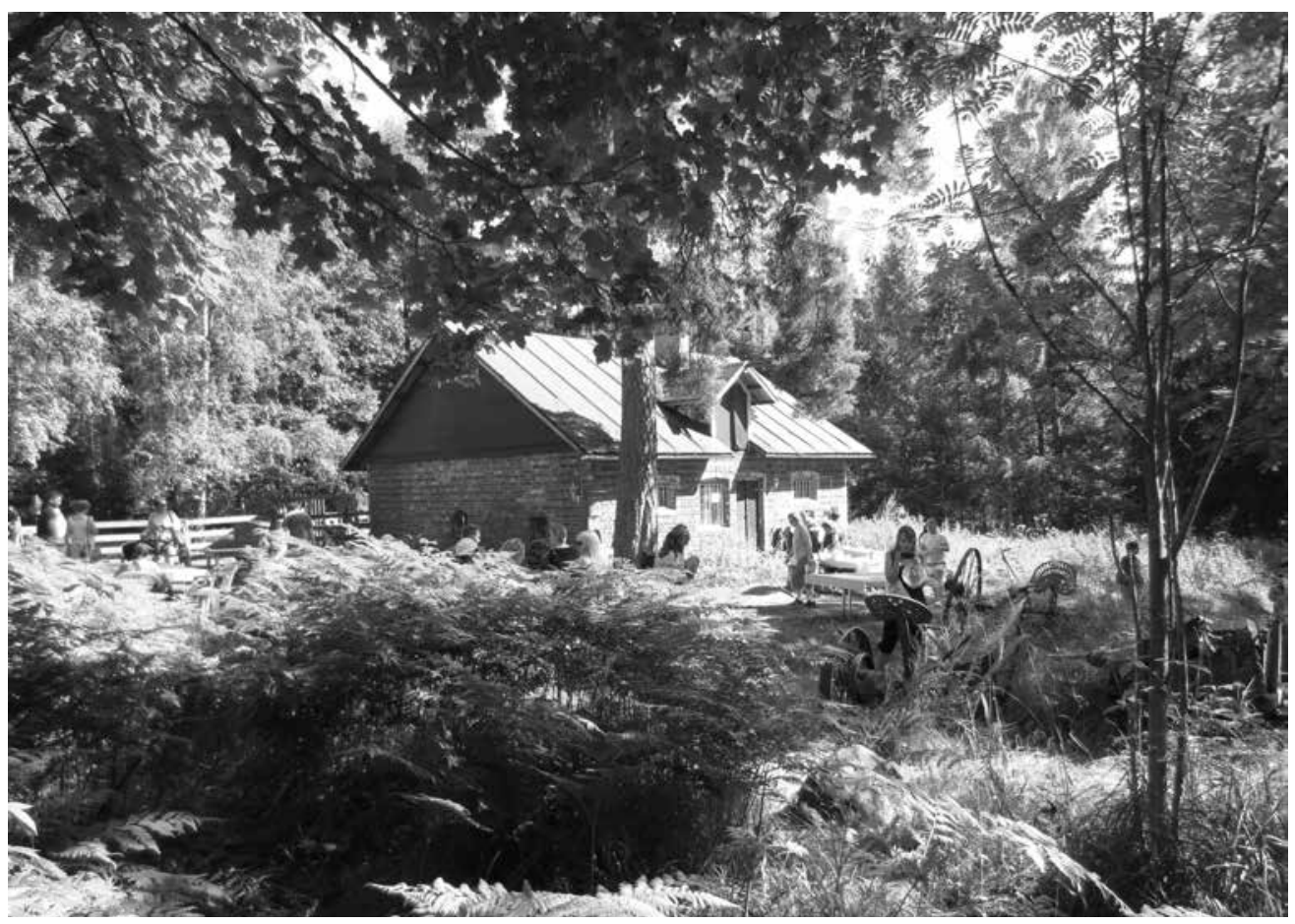

Source: Eeva Berglund

\section{Vartiosaari}

As an urban green space, Vartiosaari (Figure 2) is truly remarkable. The cultural and biological diversity on this 80-hectare island has largely survived because there is no bridge to the mainland and residents must rely on their own boats or maintain a path over the ice when feasible in winter. Designated as valuable for cultural heritage in 2009, in 2013 new planning principles were adopted for the area that aimed to turn it into a densely inhabited urban neighbourhood with recreational elements (City of Helsinki Planning Committee 2015). The island is host to a cluster of country villas, itself significant given the paucity of surviving built heritage in Finland. In the plans put forward, these would have been left to decorate the island's coast. Meanwhile, the hilly interior of the island would have been opened up to provide new housing for up to 7000 inhabitants. 
In response to these plans, many individuals and groups found opportunities to promote more genuine sustainability on and around the island. Artists including the international art and activism gathering Camp Pixelache in $2014,{ }^{6}$ for instance, and the Arts in the Environment Nordic Symposium in 2017 (see references) drew critical people and radical thinking to the island from Finland and beyond. Activists were incensed by a host of issues, like the way the planning acknowledged but belittled the significance of expert-backed claims about exceptional cultural and biological heritage. Many also perceived a cynical attack by perceived elites on a place where, due to its tiny population and apparent marginality, major construction was perhaps expected to raise few objections.

Activist resistance also recognized that development in Vartiosaari would doubtless involve knock-on effects in other eastern neighbourhoods. Social media e.g. the Facebook group Pelastetaan/Save Vartiosaari (n.d.), blogs, articles in and letters to newspapers, and local radio shows routinely featured people voicing their outrage at the way the city presented its refashioning of the island as a step towards a more sustainable Helsinki. For example, a notionally green light-rail route through some of these suburbs was a core element of the city's plans. This would have opened up this part of eastern Helsinki to further suburbanization, offering up yet more land for the city's processes of (eco)modernization.

The City of Helsinki's plans were dismissed in November 2018 by Finland's Supreme Administrative Court (Vartiosaari.fi 2018), after a series of consultations, votes and court rulings.

Examining the history of the area, it appears that this round of efforts to turn notionally "empty" land into profitable real-estate was only the latest in a series of negotiations between the city, the construction sector and different landowners, including one of the major banks in the country but also the city itself (a major landowner in Helsinki). This history has specific nuances, but it also reflects the kind of elite-driven urban politics that Molotch wrote about. In the media-friendly controversy, municipal planning seemed to be serving not people or nature but profit, leaving many people worried that something of local value - cultural and natural heritage - would disappear into financial circuits far away.

The Vartiosaari development plans did not succeed, but they - and resistance to them demonstrate a tenacious ideological adherence to urban growth principles. The development of the brownfield area of Kalasatama, perhaps moves up a register in the pairing of technocracy and financialization. Further, it leverages the added lustre of anything associated with sustainability.

\section{Kalasatama}

Kalasatama, nearer the central core of Helsinki, is presented as a formerly dirty place being turned into nice, clean, green living. Work began around 2005 with a new metro station that cost $€ 16$ million. However, it is only in the last five years that Kalasatama has begun to really take shape. At the time of writing, there are around 3,600 people living there.

An instructive online video made by activists at the time, can be found at https://youtu.be/qeibkl8ea3s. Accessed May 19, 2020. 
By 2040 , there should be 26,000 housed in Kalasatama, which will also provide 8,000 jobs and 400,000 square meters of office space. It is conceived as a smart neighbourhood. Forum Virium Helsinki, a City of Helsinki Innovation Company, provides a platform for companies to develop digital and other services for the neighbourhood. This is centred on the provision of open data, which can then be worked with by start-ups and enthusiastic citizens. Forum Virium Helsinki supports such initiatives as domestic energy efficiency systems through data utilization, situational mobility analysis and awareness, robotic minibuses, a well-being living-lab pilot programme, smart domestic lighting systems for the elderly and the piloting of Decentralised Citizens Engagement Technologies. Digital, business, investment and social layers get added onto each other to produce an intensified neighbourhood, both in terms of lived experience and in terms of financial investment. Indeed, a key marketing line for Kalasatama is that it will become so efficient that its citizens will each save an hour a day (Fiksukalasatama 2015).

But we may also understand this intensification of Kalasatama as a process of a particular type of rationalization, a way of ordering and fixing the surplus capital generated in the global political economy. Indeed, it is noteworthy how many of Kalasatama's key buildings - such as the major health centre, which also serves residents in neighbouring suburbs who previously had facilities closer to home, or its shopping mall - are financed by big institutional investors. Two major construction companies, SRV and Skanska, are active in Kalasatama. Pension funds and insurance companies provide the financial bedrock of its construction, however. Among these are pensions companies such as Varma, Ilmarinen Mutual Pension Insurance Company, OP-Vuokratuotto Investment Fund Insurance Ltd., OP Life Assurance Company Ltd. and the OP Pension Fund. Additionally, real estate companies such as Deka Immobilien and Union Investment Real Estate GmbH act on behalf of thirdparty institutional investors and individual shareholders.

Thus, it is important to view the seemingly frictionless flows of finance as being closely bound into the material friction of the everyday world of Kalasatama. The latter is carefully formatted, that is, designed, in service to the former. This relationship is neatly summarized by Harvey in the following, often-quoted words, taken from The Urban Experience.

Capital flow presupposes tight temporal and spatial coordination in the midst of increasing separation and fragmentation. It is impossible to imagine such a material process without the production of some kind of urbanization as a "rational landscape" within which the accumulation of capital can proceed. Capital accumulation and the production of urbanization go hand in hand. (Harvey 1989: 22).

The "green" progress in Kalasatama, then, is integral to the very dynamics that accelerate environmental damage. What appears in any part of the world as rationalized, quantified and context-free information about profits and losses is materialized here with local and regional as well as possibly global consequences. In the most practical terms, construction alters environments and puts pressure on daily routines and quality of life. As large-scale building generates new structures, promises of improvements are partial at best. Although the harbour functions that once dominated where Kalasatama is today have been moved elsewhere, and their environmental bads removed, the safe and clean environments 
of twenty-first-century digital smartness remain open to critique as harbingers of a consumerled, monetized future with a financial, more than a democratic, mandate and with question marks remaining over their sustainability.

As these two examples show, and as Hyötyläinen and Haila (2018) argue, planning to support the legitimate public good as well as genuine sustainability is difficult in Helsinki at the moment. Municipal politics are subordinated to efforts to capture wealth as profits and taxes, even as they are supposed to address the social and ecological damages produced by this capture. Being climate-friendly and user- or human-centred is ultimately less important than attracting the investors known as developers and the proverbial "good taxpayers". Here too, Molotch's observations were insightful: "growth comes at a cost to existing residents, while transferring wealth from the general public to a certain segment of the local elite" (1976: 320; emphasis added).

Molotch drew attention to the contradictions that arise when "land, the basic stuff of place, is a market commodity providing wealth and power" (1976: 309). Fixing attention on the USA, he painted a picture of urban government as a mosaic of constantly competing interest groups with one overarching shared goal, growth. His hope was to render visible this ignored "essence of local government". He also showed how the idea of the city as a growth machine supported the interests of wealthy elites, but became ingrained as an unremarkedupon but fundamental feature of American urban politics, supported not just by the wealthy but by all. The situation he described is even more entrenched today: "Largely unseen, and relegated to negotiations within committees (when it occurs at all within a formal government body) ... the politics which determines who, in material terms, gets what, where, and how (...). This is the kind of politics we must talk about at the local level: it is the politics of distribution, and land is the crucial (but not the only) variable in this system" (1976: 313-314; italics in original).

Today the problem goes well beyond elites. The growth model has been successfully integrated into decision making in Finland (Hyötyläinen and Haila 2018; Granqvist et al. 2019). And though the research on urban development in Helsinki that we cite is critical, it does not take issue with the goal of urban and economic growth itself.

\section{Conclusion: The WEIRDness of the Growth Syndrome}

Western democracies are not ruled by kings or priests, but by a shared belief, the ideology of economic growth. Degrowth thinker Serge Latouche even argues that "we do indeed have to abandon a faith or a religion - and reject the irrational and quasi-idolatrous cult of growth for growth's sake" (2009: 9). Core to legitimate government to the point of being unnoticeable, its rule can be found in hundreds of thousands of policy documents and un-reflexive conversations. Though subject to increasing critique, the ideology of growth is likely - for the foreseeable future - to reproduce itself despite the humanitarian and environmental costs.

But what if we align with those who do not take the urban growth imperative as foundational? What if we insist that the problem to be explained is the growth syndrome itself? Adopting what anthropologist Stuart Kirsch (2014) calls a "reverse anthropology" 
strategy where common-sense capitalist practices are interpreted from alternative commonsense worlds, we can view the endlessly growing socio-technico-ecological world that we inhabit as astonishingly weird.

We find that psychologists have also generated grounds for such an exercise by arguing that what passes for research about human life in general turns out to be unrepresentative of the "vast majority of the world's population" (Nielsen et al. 2017: abstract). Using their acronym, we could ask, what is the impact of imagining people or humanity as if all that mattered were the governing classes and their WEIRD psychologies: Western - Educated Industrial - Rich - Democracies. Nielsen et al. argue that since psychology research is mostly done by WEIRD institutions with overwhelmingly WEIRD participants, surely researchers and their potentially influential audiences should be "attentive to the possibility that where we think we are exploring human universals, we are rather exploring cultural specifics" (2017: 36). They critique developmental psychology for marginalizing through "othering" while treating WEIRD participants as the norm (p. 35).

Like the peculiarities of WEIRD experimental subjects, the urban growth imperative is barely even identified as a phenomenon despite its problematic history and the fact that its ecological and social damages have only intensified since Molotch's intervention. Certainly, there have been many critical voices (going back to Lewis Mumford's essays in the 1920s and others before him) decrying thoughtless admiration of urban growth and the pernicious impacts of the growth ideology. And yet, many of those who consider themselves critics, even radical critics, of economic growth express a resignation that surely nothing can be done since it is natural to seek growth and that humans are by nature competitive. In fact, both claims - and others supporting the hegemony of neoliberal discourse - can be refuted, as ample research from "othered" points of view - decolonizing, feminist, queer, socialist and so on - shows (see Nielsen et al. 2017).

In addition to highlighting the practical problems and conceptual aporias of the growth syndrome, should we not enquire into how as a group, the moderns or the neoliberals or all those for whom economic growth is the be-all and end-all of existence, made it appear that it is also the foundation of civilization? If that's a grandiose task, a more practical one is to explore capitalist culture and history as seriously peculiar. A starting point could be showing how, within less than a century, it has become so common-sensical that something called "the economy" should grow (e.g. Mazzucato 2018). Before, it was simply companies, and before companies it was all kinds of things, though with these growth generally also gave way to decay and death.

When a city becomes a growth machine and therefore something to be rationalized, technocrats gain power and politics are corroded. In its current obdurate conjuncture, this means financialization, and this means particular material constructions.

Helsinki's conflicts highlight party politics and individual human failings. The bigger argument about the harm of growth is lost in local details or accepted with resignation. Besides, as Molotch also pointed out, many activists can only guess at what happens behind closed doors. And although it is great academic sport to carefully unpack the contradictions inherent in green growth agendas as fugitive yet consequential shape-shifting processes of neoliberalization, it has so far had little political impact. 
Yet our point is that the troubles created by the growth machine do not just emerge from the qualities of corporations and the elites running them. We have argued that they are deeply entrenched in cultural habits and ways of thinking. The growth agenda is repeatedly hardwired into everyday life and even environmental policy, which means it is quite easy to take the political out of environmental politics. We find, however, that the depoliticization is only partial. Activist-research on environmental change in Finland is ever more strident in linking the winners to the losers, glitzy novelties to their displaced costs. It points out the absurd mathematics of piling growth rates on growth rates, as well as to the weirdness of talking about Helsinki as the new New York City. Recent research on these themes (Heikkurinen 2018; Lehtinen 2018) is part of a discernible shift in environmentalist and social discourse towards some kind of degrowth thinking even if those involved do not profess allegiance to a movement as such. Rather, the Finnish vocabulary is that of "sufficiency" (kohtuullisuus).

Around the world, critical geographers and social scientists, heterodox economists and social movement scholars (see References) are intensifying empirical research on the multiple crises of neoliberal capitalism and its costs. For example, writing of wealthy publics not unlike those we find in Helsinki, Schlosberg and Coles (2016) spell out the reality of a diffuse but evident "sustainable materialism, environmentalism of everyday life" that responds to the political "alienation and resultant destruction of the non-human realm" (2016: 161). With a focus on industrialized countries, they show how widespread the "modes of organization, forms of resistance, and prefigurative models of democratic living" (p. 161) already are that take a serious maladaptation between humans and nonhumans as their key challenge. What needs explaining, then, is not why or how people might resist growth, or how to make degrowth sound more appealing or less vague, but why something so peculiar as the growth syndrome - weird - has not been debunked long ago.

\section{Acknowledgements}

Thanks to the countless people who have guided us through their changing cityscapes and their problems. Thanks to Helen Soovali-Sepping, Barbora Hubatková, Bianka PlüschkeAltof, Katri-Liisa Pulkkinen, to the organizers of the Helsinki Sustainability Science Days panel on Degrowth and postgrowth in May 2019, Pasi Heikkurinen and Eeva Houtbeckers, and to the very helpful reviewers.

\section{References}

Ameel, Lieven. 2016. "Emplotting Urban Regeneration: Narrative Strategies in the Case of Kalasatama, Helsinki." Rajaniemi, J. ed.: DATUTOP 34: 222-240.

Arjanko, Timo. 2015. Dwellings Promoting Sustainable Lifestyles in Vartiosaari. Aalto University, School of Art, Design and Architecture, Master's thesis.

Arts in the Environment Nordic Symposium 2017. Online information. Retrieved May 19, 2020 (http://www.nordicenviroart.org/). 
Asafu-Adjaye, John et al. 2015. An Ecomodernist Manifesto. Retrieved May 18, 2020 (https:// www.ecomodernism.org).

Bennie, Claire. 2015. "Helsinki: Jätkäsaari + Arabia." Retrieved February 20, 2020 (http:// bennieontheloose.com/helsinki-jatkasaari-arabia).

Berglund, Eeva. 2001. "Facts, Biases, and Constructions: Perspectives on Forest Conservation in Finland." Journal of Environmental Planning and Management 44(6): 833-849.

Berglund, Eeva and Cindy Kohtala, eds. 2015. Uusi Helsinki? Det Nya Helsingfors? Changing Helsinki?: 11 näkökulmaa kaupungin mahdollisuuksiin. Helsinki: Kustannusosakeyhtiö Nemo.

Berman, Marshal. 1982 All that is Solid Melts into Air. New York: Penguin.

Blühdorn, Ingolfur and Michael Deflorian. 2019. "The Collaborative Management of Sustained Unsustainability: On the Performance of Participatory Forms of Environmental Governance." Sustainability 11(4): 1189.

Chertkovskaya, Ekaterina, Alexander Paulsson, Girogos Kallis, Stefania Barca, and Giacomo D'Alisa. 2017. "The Vocabulary of Degrowth: A Roundtable Debate." Ephemera: Theory and Politics in Organization 17(1): 189-208.

City of Helsinki. 2013. Helsinki City Plan: Vision 2050. Helsinki: City Planning Department.

CityofHelsinki.2015.PlanningCommittee,Agenda/Helsinginkaupunki-Kaupunkisuunnittelulautakunta, Esityslista, May 12, 2015.

Davidson, Mark. 2010. "Sustainability as Ideological Praxis: The Acting out of Planning's MasterSignifier.” City 14(4): 390-405.

Demaria, Federico, Giorgos Kallis, and Karen Bakker. 2019. "Geographies of Degrowth: Nowtopias, Resurgences and the Decolonization of Imaginaries and Places." Environment and Planning E: Nature and Space 2(3): 431-450.

Fiksukalasatama. 2015. "Explore Kalasatama in Helsinki." Retrieved October 4, 2019 (https:// fiksukalasatama.fi/wp-content/uploads/2015/08/Fiksu_KS_MIPIM_FINAL_web_pages.pdf).

Fortun, Kim. 2014. "From Latour to Late Industrialism." HAU: Journal of Ethnographic Theory 4(1): 309-329.

Fredriksson, Peter and Pekka Normo. 2019. "Asumisen ja maankäytön politiikka arvioitava uudelleen.” Yhdyskuntasuunnittelu-lehti 57(2): 51-55.

Glancey, Jonathan. 2015. "Here and Nowhere Else." Pp. 123-131 in Changing Helsinki? 11 Views on a City Unfolding, edited by Eeva Berglund and Cindy Kohtala. Helsinki: Nemo.

Granqvist, Kaisa, Sauli Sarjamo, and Raine Mäntysalo. 2019. "Polycentricity as Spatial Imaginary: The Case of Helsinki City Plan.” European Planning Studies 27(4): 739-758.

Hall, Tim and Phil Hubbard. 1996. "The Entrepreneurial City: New Urban Politics, New Urban Geographies?" Progress in Human Geography 20(2): 153-174.

Hamilton, Clive. 2015. "The Theodicy of the 'Good Anthropocene'.” Environmental Humanities 7(1): 233-238.

Hannikainen, Matti O. 2019. "Planning a Green City: The Case of Helsinki, 2002-2018." Pp. 121-134 in Planning Cities with Nature: Theories, Strategies and Methods, edited by Fabiano Lemes de Oliveira and Ian Mell. Springer.

Harvey, David. 1989. The Urban Experience. Oxford: Basil Blackwell.

Harvey, David. 1996. Justice, Nature and the Geography of Difference. Cambridge, MA and Oxford: Blackwell.

Haughton, Graham, Iain Deas, and Stephen Hincks. 2014. "Making an Impact: When Agglomeration Boosterism Meets Antiplanning Rhetoric." Environment and Planning A 45(2): 265-270.

Heikkurinen, Pasi. 2017. Sustainability and Peaceful Coexistence for the Anthropocene. Routledge.

Helsingin Sanomat. 2019. Front-page advertisement for SRV, September 22, 2019. 
Helsinki City Strategy 2017-2021: The Most Functional City in the World. Retrieved May 15, 2020 (https://www.hel.fi/helsinki/en/administration/strategy/strategy/city-strategy/).

Heynen, Nik, Maria Kaika, and Erik Swyngedouw, eds. 2006. In The Nature of Cities: Urban Political Ecology and the Politics of Urban Metabolism. London: Routledge.

Hyötyläinen, Mika and Anne Haila. 2018. "Entrepreneurial Public Real Estate Policy: The Case of Eiranranta, Helsinki." Geoforum 89: 137-144.

Ilta Sanomat. 2017. "IS-raportti." Retrieved February 20, 2020 (https://www.is.fi/kotimaa/art2000005232656.html).

James, Paul. 2014. Urban Sustainability in Theory and Practice: Circles of Sustainability. Abingdon: Routledge.

Julier, Guy. 2005. "Urban Designscapes and the Production of Aesthetic Consent." Urban Studies 42(5-6): 689-688.

Julier, Guy. 2011. "Design Activism Meets Place-Branding: Reconfiguring Urban Representation and Everyday Practice." Pp. 221-238 in Brand and Branding Geographies, edited by Andy Pike. London: Edward Elgar.

Julier, Guy. 2017. Economies of Design. London: SAGE Publications.

Kaika, Maria. 2017. “'Don’t Call Me Resilient Again!': The New Urban Agenda as Immunology ... or ... What Happens when Communities Refuse to be Vaccinated With 'Smart Cities' and Indicators." ENVIRONMENT and URBANIZATION 1: 89-102.

Kaupunkiaktivismi / Civic Activism as Resource for the Metropolis website. Retrieved February 20, 2020 (https://kaupunkiaktivismi.wordpress.com/2016/12/04/jalkistalistinen-hirviovai-suunnittelukeskustelun-uudistaja-laiturilla-ruodittiin-lisaa-kaupunkia-helsinkiin-ryhmaa/).

Kirsch, Stuart. 2014. "Social Relations and the Green Critique of Capitalism in Melanesia." American Anthropologist 110(3): 288-298.

Kotilainen, Juha, Maija Halonen, Eero Vatanen, and Markku Tykkyläinen. 2016. "Resource Town Transitions in Finland." Chapter 12 in Transformation of Resource Towns and Peripheries: Political Economy Perspectives, edited by Greg Halseth. Abingdon: Routledge.

Kysela, Eva. 2015. "Acceptability of Environmental Policies in the Czech Republic: A Comparison with Willingness to Make Economic Sacrifices.” Sociální studia / Social Studies 12(3): 179-198.

Latouche, Serge. 2009. Farewell to Growth. Cambridge: Polity Press.

Lawrence, Jessica C. 2017. "Managing the Environment: Neoliberal Governmentality in the Anthropocene." Pp. 68-84 in Sustainability and Peaceful Coexistence for the Anthropocene, edited by Pasi Heikkurinen. Abingdon: Routledge.

Lehtinen, Ari A. 2018. "Degrowth in City Planning." Fennia 196(1): 43-57.

LisääkaupunkiaHelsinkiinFacebookgroup.N.d.RetrievedFebruary20,2020(https://www.facebook.com/ groups/184085073617/).

Luke, Timothy W. 1995. "On Environmentality: Geo-Power and Eco-Knowledge in the Discourses of Contemporary Environmentalism." Cultural Critique 31: 57-81.

Mazzucato, Mariana. 2018 The Value of Everything: Making and Taking in the Global Economy. London: Allen Lane.

Mirowski, Philip. 2013. Never Let a Good Crisis Go to Waste: How Neoliberalism Survived the Financial Meltdown. London and New York: Verso.

Nielsen, Mark, Daniel Haun, Joscha Kärtner, and Cristine H. Legare. 2017. "The Persistent Sampling Bias in Developmental Psychology: A Call to Action.” Journal of Experimental Child Psychology 162: 31-38.

Niemelä, Jari. 2018. Kestävän kehityksen kaupunkipolitiikka, pp. 64-67. Retrieved May 15, 2020 (https://www.hel.fi/static/helsinki/julkaisut/kaupunkien-aikakausi-2018.pdf). 
Oinonen, Okko. 2015. Save Vartiosaari FLASH MOB video. Retrieved may 15, 2020 (https://youtu.be/ JO3I569qBF4).

Peck, Jamie, Nik Theodore, and Neil Brenner. 2009. "Postneoliberalism and its Malcontents." Antipode: A Radical Journal of Geography 41(6): 94-116.

Pelastetaan/ Save Vartiosaari Facebook group. N.d. Retrieved May 19, 2020 (https://www.facebook.com/ pelastetaanvartiosaari).

Quilley, Stephen. 2000. "Manchester First: From Municipal Socialism to the Entrepreneurial City." International Journal of Urban and Regional Research 24(3): 601-615.

Sairinen, Rauno. 2003. "Environmental Governmentality as a Basis for Regulatory Reform: The Adaptation of New Policy Instruments in Finland.” Available online via ECPR.eu, retrieved October 4, 2019.

Schlosberg, David and Romand Coles. 2016. "The New Environmentalism of Everyday Life: Sustainability, Material Flows and Movements." Contemporary Political Theory 15(2): 160-181.

Schulman, Harry and Pasi Mäenpää, eds. 2011. Kaupungin kuumat lähteet. Helsingin metropolialueen innovaatioympäristöt. Helsinki: Helsingin kaupungin tietokeskus.

Smart Kalasatama - Smart City District of Helsinki. n.d. Online by Forum Virium Helsinki. Retrieved May 15, 2020 (https://fiksukalasatama.fi/en/smart-city/).

Springer, Simon. 2012. "Neoliberalism as Discourse: Between Foucauldian Political Economy and Marxian Poststructuralism." Critical Discourse Studies 9(2): 133-147.

Vartiosaari.fi. 2018. "Korkein hallinto-oikeus vahvisti Vartiosaaren Osayleiskaavan Kumoamisen ja ..." Retrieved February 20, 2020 (http://www.vartiosaari.fi/uudet sivut/uncategorized/korkeinhallinto-oikeus-vahvisti-vartiosaaren-osayleiskaavan-ja-helsingin-yleiskaavan-kumoamisenvartiosaaren-osalta/).

Swyngedouw, Erik. 2013. "The Non-Political Politics of Climate Change." ACME: An International Journal for Critical Geographies 12(1): 1-8.

Unsworth, Rachael, Sue Ball, Irena Bauman, Paul Chatterton, Andrew A. Goldring, Katie Hill, and Guy Julier. 2011. "Building Resilience and Wellbeing in the Margins within the City: Changing Perceptions, Making Connections, Realising Potential, Plugging Resources Leaks." City 15(2): 181-203.

Uudenmaan Maakuntahallitus, minutes of meeting. Retrieved September 9, 2019 (https://www. uudenmaanliitto.fi/dynastia32/cgi/DREQUEST.PHP?page=meeting\&id=20193314).

Uutta Helsinkiä website n.d. Retrieved September 29, 2019 (https://www.uuttahelsinkia.fi/en).

Vanolo, Alberto. 2008. "Internationalization in the Helsinki Metropolitan Area: Images, Discourses and Metaphors." European Planning Studies 16(2): 229-252.

Vapaavuori, Jan. 2018. "Esipuhe (Preface)." In Helsinki Symposium: Kaupunkien aikakausi Kaupunkitutkijoiden puheenvuoroja 2020-luvun kaupunkipolitiikastan [The Urban Era - Urban Scholars' Perspectives on the Urban Policy of the 2020s]. Retrieved May 15, 2020 (https://www. hel.fi/static/helsinki/julkaisut/kaupunkien-aikakausi-2018.pdf).

Wallin, Sirkku. 2018. "Katsantoja kaupungin muutokseen." Yhdyskuntasuunnittelu-lehti 56(4): 11-27.

While, Aidan, Andrew E. G. Jonas, and David Gibbs. 2004. "The Environment and the Entrepreneurial City: Searching for the Urban 'Sustainability Fix' In Manchester and Leeds.” International Journal of Urban and Regional Research 28(3): 549-569.

YLE. 2019. "Yle Luonnon kysely: Suomalaiset asettavat luonnon talouskasvun edelle - huoli luonnon monimuotoisuudesta kasvaa [Finns Put Nature Ahead of Economic Growth - Concern about Biodiversity is Growing].” Retrieved September 28, 2019 (https://yle.fi/aihe/artikkeli/2019/09/28/ yle-luonnon-kysely-suomalaiset-asettavat-luonnon-talouskasvun-edelle-huoli). 


\section{Authors}

Eeva Berglund, Adjunct Professor, Department of Design, Aalto University, Helsinki. She gained her doctorate in social anthropology and has a master's degree in spatial planning, both from the UK. Her academic work concerns grassroots urbanism, environmental social movements, urban development and transformations in notions of expertise.

Contact: eeva.berglund@aalto.fi

Guy Julier, Professor of Design Leadership and Head of Research, Department of Design, Aalto University, Helsinki. He is a writer, academic and practitioner with over 30 years professional experience observing and researching global and local interrelationships of design, economics and society.

Contact: guy.julier@aalto.fi 